\title{
Communications between Mitochondria and Endoplasmic Reticulum in the Regulation of Metabolic Homeostasis
}

\author{
Pengcheng Zhang, Daniels Konja, Yiwei Zhang and Yu Wang * (D) \\ The State Key Laboratory of Pharmaceutical Biotechnology, Department of Pharmacology and Pharmacy, \\ The University of Hong Kong, Hong Kong SAR, China; u3005061@connect.hku.hk (P.Z.); \\ kdaniels-1@outlook.com (D.K.); u3005377@connect.hku.hk (Y.Z.) \\ * Correspondence: yuwanghk@hku.hk
}

\begin{abstract}
Mitochondria associated membranes (MAM), which are the contact sites between endoplasmic reticulum (ER) and mitochondria, have emerged as an important hub for signaling molecules to integrate the cellular and organelle homeostasis, thus facilitating the adaptation of energy metabolism to nutrient status. This review explores the dynamic structural and functional features of the MAM and summarizes the various abnormalities leading to the impaired insulin sensitivity and metabolic diseases.
\end{abstract}

Keywords: mitochondria; endoplasmic reticulum; MAM; energy metabolism

Citation: Zhang, P.; Konja, D.; Zhang, Y.; Wang, Y. Communications between Mitochondria and Endoplasmic Reticulum in the Regulation of Metabolic Homeostasis. Cells 2021, 10, 2195. https://doi.org/ 10.3390/cells10092195

Academic Editors: In-Kyu Lee and Dipanjan Chanda

Received: 8 July 2021

Accepted: 16 August 2021

Published: 25 August 2021

Publisher's Note: MDPI stays neutral with regard to jurisdictional claims in published maps and institutional affiliations.

Copyright: (c) 2021 by the authors. Licensee MDPI, Basel, Switzerland. This article is an open access article distributed under the terms and conditions of the Creative Commons Attribution (CC BY) license (https:// creativecommons.org/licenses/by/ $4.0 /)$.

\section{Introduction}

In mammalian cells, the mitochondrion is the organelle specialized for energy production through the processes of oxidative phosphorylation, tricarboxylic acid (TCA) cycle and fatty acid $\beta$-oxidation [1]. Approximately $90 \%$ of cellular reactive oxygen species (ROS) are produced from mitochondria during the reactions of oxidative phosphorylation (OXPHOS) via the electron transport chain (ETC) [2]. As an essential powerhouse of mammalian cells, the mitochondrion is crucial for functional regulation of cellular processes, including metabolism, proliferation, survival and death [3-5]. Mitochondrial integrity is maintained through a series of quality control processes such as the mitochondrial unfolded protein response (UPR ${ }^{\mathrm{mt}}$ ), antioxidant defense, fusion and fission, biogenesis and mitophagy-mediated removal [6,7]. The function of mitochondria decreases with advancing age, and dysfunctional mitochondria are implicated in the development and progression of metabolic diseases. However, accumulating evidence shows that alterations in mitochondria may evoke defense mechanisms to elicit coordinated protective effects on metabolic health and life span $[8,9]$.

Endoplasmic reticulum (ER) is a membrane-bound organelle that controls the synthesis, folding, maturation and intracellular transport of proteins. ER also plays an essential role in regulating intracellular calcium homeostasis and lipid metabolism [10,11]. Increased demand for protein synthesis and aggregation of misfolded proteins are the main triggers for ER stress and unfolded protein response $\left(\mathrm{UPR}^{\mathrm{ER}}\right)$, a conserved transcriptional and translational program to stimulate chaperone production and restore proteostasis [12,13]. During UPR ${ }^{\mathrm{ER}}$, the sensor molecules anchored at the ER membrane, including inositolrequiring enzyme 1 (IRE1), activating transcription factor 6 (ATF6) and RNA-dependent protein kinase (PKR)-like ER kinase (PERK), are activated to transduce signals for the induction of various cellular responses [14]. The defective proteins are transported to the cytoplasm for degradation. This process is referred to as ER-associated degradation (ERAD) [15]. In mammals, ER stress represents a defense mechanism that helps the cells to adapt and survive. However, prolonged ER stress increases the risk of metabolic diseases such as obesity, insulin resistance, diabetes and fatty liver injuries [16-19]. 
The function and stress signaling of mitochondria and ER are dynamically intertwined, especially in the context of metabolic regulation [20]. ER stress leads to altered mitochondrial structure and function, as well as impaired glucose/lipid homeostasis [21,22]. Disruption in the normal function of mitochondria results in ER stress activation, which induces aberrant insulin signaling $[23,24]$. As the powerhouse and the building factory of the cells, mitochondria and ER are not only functionally but also structurally linked [20]. The physical contacts between the membranes of the ER and mitochondria are called mitochondria-associated membranes (MAM), ER-mitochondria encounter structure (ERMES) or ER membrane protein complex (EMC) $[25,26]$. MAM allow the exchange of different ions and metabolites, and play important roles in regulating mitochondrial dynamics/bioenergetics, calcium homeostasis, lipid metabolism, mito/autophagy and cellular apoptosis [20,27]. MAM mark the sites for mitochondrial DNA (mtDNA) synthesis and dynamic regulation [28-30]. ER-mitochondria contacts coordinate mtDNA replication with downstream mitochondrial division to distribute newly replicated mtDNA to the daughter mitochondria [30]. Targeting mitochondria and ER crosstalk represents a promising therapeutic approach for numerous diseases, including metabolic and cardiovascular disorders, neurodegeneration and cancer, as well as the aging process. The present review focuses on the structure and function of MAM and its role in mediating the molecular crosstalk between mitochondria and ER under healthy and abnormal metabolic conditions.

\section{Structure of MAM}

The physical interaction between ER and mitochondria was first proposed over 60 years ago [31,32]. However, such observations were considered artifacts of fixation for a long time. In the 1990s, the existence of MAM was confirmed by biochemical isolation, immunofluorescence labeling and immunoelectron microscopy [33-36]. The interface of MAM is formed by bringing the two phospholipid bilayers of ER and mitochondria into close proximity (Figure 1). The approximate distance from the outer membrane of mitochondria (OMM) to the ER was originally estimated to be $\sim 100 \mathrm{~nm}$ [37]. Subsequent studies using electron tomography reveal a much shorter distance of $\sim 10-50$ and $\sim 50-80 \mathrm{~nm}$, respectively, between OMM and the smooth or rough ER [38,39]. The extent of interactions at the juxtaposition between the two organelles appears to be an important parameter of MAM function [40,41]. The formation of MAM relies on proteins expressed on membranes of both ER and mitochondria, which interact either directly or indirectly by forming multiprotein-tethering complexes [42]. Mass spectrometry-based proteomic studies have identified over 1000 proteins participating in the structural and functional interactions at either human or animal MAM samples [43,44]. For example, the ATPase family AAA domain-containing protein 3 (ATAD3) is a single-protein linker for MAM [45]. The vesicleassociated membrane protein $\mathrm{B}$ (VAPB), an ER-resident protein, interacts with the tyrosine phosphatase-interacting protein-51 (PTPIP51), an OMM protein to form a complex at MAM [46-48]. The ER resident inositol triphosphate receptors (IP3R) physically interact with the cytosolic fraction of the mitochondrial chaperone $75 \mathrm{kDa}$ glucose-regulated protein (GRP75) [49], and the voltage-dependent anion channel (VDAC), a porin ion channel allowing calcium flow through the OMM [50]. The IP3R-GRP75-VDAC tethering complex mediates release of calcium from the ER and the uptake of calcium by mitochondria to stimulate oxidative metabolism [51] (Figure 1).

Proteins that participate in the fission and fusion of mitochondria, including dynaminrelated protein 1 (DRP1) in mammals, dynamin 1 (DNM1) in yeast, mitofusion (MFN) 1 and MFN2, are part of MAM [52,53] (Figure 1). MFN2 at MAM forms homo- and heterodimers with mitochondria-localized MFN2 and MFN1, respectively [54]. Deletion of MFN2 reduces mitochondrial calcium uptake induced by inositol-1,4,5-triphosphate (IP3) and causes significant changes in the ER morphology [54]. Ubiquitination of MFN2 by mitochondrial ubiquitin ligase (MITOL) downregulates ER-mitochondria interactions [55]. Phospho-ubiquitination of MFN2 by PTEN-induced kinase 1 (PINK1) and Parkinson protein 2 E3 ubiquitin protein ligase (PARKIN) also triggers the disassembly of ER- 
mitochondria tethering complexes to drive mitophagy [56]. The PINK1/MFN2/PARKIN pathway is required by the healthy mitochondria to communicate with ER [57]. The presence of MFN2 at MAM facilitates other molecules such as presenilin 2-mediated ERmitochondrial interactions [58]. Fission and fusion events regulate the structure, distribution and function of mitochondria. ER tubules at MAM are responsible for the constriction of membrane for mitochondrial division [28]. The mitochondrial fission 1 (FIS1), an OMM protein, recruits DRP1 to mitochondrial fission sites [59]. When FIS1 interacts with the B cell receptor-associated protein 31 (BAP31), an ER chaperone located at MAM, apoptosis is induced [60]. BAP31 also interacts with other mitochondrial proteins, including translocase of outer mitochondrial membrane 40 (Tom40), to stimulate the translocation of NADH dehydrogenase (ubiquinone) iron-sulfur protein 4 (NDUFS4), a component of ETC complex I. Disruption of the BAP31-Tom40 tethering complex inhibits mitochondrial ETC complex I activity and oxygen consumption [61].

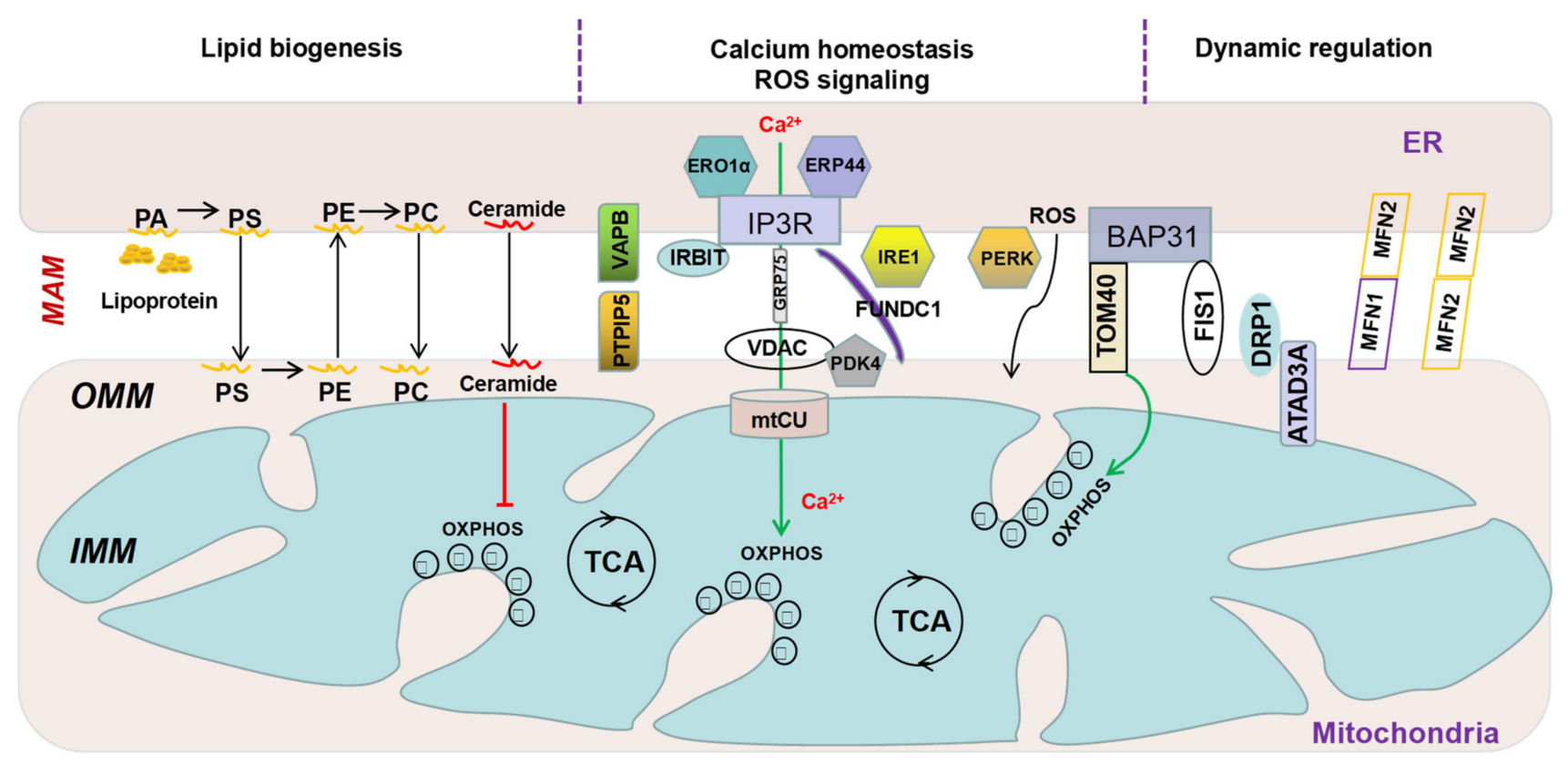

Figure 1. Schematic illustration of the tethering complexes at MAM.

\section{MAM and Lipids Biogenesis}

MAM possess the ability to synthesize and facilitate the interorganellar exchange of phospholipids and sterols [62,63]. MAM support a robust incorporation of $3 \mathrm{H}$-serine and subsequent conversion into 3H-phosphatidylserine (PS) and 3H-phosphatidylethanolamine (PE) [34]. Various phospholipids, triglycerides, cholesterols and cholesterol esters are present at MAM, which are enriched with enzymes such as diacylglycerol acyltransferase, acyl-coenzyme A, cholesterol acyltransferase, phosphatidylserine synthase, phosphatidylethanolamine N-methyltransferase, PE methyltransferase, PS synthase and decarboxylase [64]. The reactions mediated by enzymes at MAM play a role in enhancing the synthetic efficiency and limiting the dis-semination of the lipid products. For example, the phospholipids generated at MAM are used for lipoprotein assembly in cells. Transport of PS from ER to mitochondria via MAM facilitates its conversion to PE $[65,66]$. MFN2 binds PS and promotes its transfer to mitochondria for PE biosynthesis [55,56,67]. In yeast, the ERMES complex acts as a transferase to mediate the non-vesicular transport of lipids [68]. In mammalian cells, the PDZ domain-containing protein 8 (PDZD8) is predicted to be structurally similar to the synaptotagmin-like mitochondrial-lipid-binding (SMP) domain proteins [69], and participated in a three-way contact between ER-late endosome and mitochondria [70]. However, it is still unclear if this protein can transport lipids. 
MAM is also considered as a pre-Golgi compartment for the assembly and secretion of lipoproteins [36]. In liver, for instance, MAM contains the microsomal triacylglycerol transfer protein (MTTP), which is required for the biogenesis of lipoproteins that contain apolipoprotein (Apo) B [67]. Nascent ApoB-containing lipoproteins obtained from the lumen of MAM show the same average density and composition as those isolated from heavy and light ER fractions, Golgi, and newly secreted by the cultured hepatocytes [36]. MAM fractions isolated from liver contain mRNA transcripts that encode various proteins for the assembly of plasma lipoprotein particles, such as MTTP, protein disulfide isomerase family A, member 1 (Pdia1), carboxylesterase 1d (Ces1d), ApoB and ApoE [71]. The presence of key components of very low density lipoprotein (VLDL) biogenesis at MAM supports its involvement in lipoprotein bio-genesis, which in turn contributes to systemic lipid metabolism and homeostasis [71].

Sphingolipids, including ceramide, sphingosine, ceramide-1-phosphate (C1P) and sphingosine-1-phosphate (S1P), modulate mitochondrial function and in turn adversely affect cellular redox and energy metabolism [72-74]. ER is the primary site for de novo sphingolipid biosynthesis in mammalian cells [75]. Ceramide is translocated through MAM to mitochondria [76,77]. Enzymes for sphingolipid biosynthesis, such as ceramide synthase, ceramidase, sphingomyelinase and sphingosine kinase, have also been detected in the mitochondria and MAM [76,78]. Various ceramide species with different acyl chain attachments are present in the membranes of mitochondria. However, ceramide accumulation inhibits mitochondrial respiration $[79,80]$. Ceramide transport to the mitochondria by ceramide transfer protein (CERT) induces apoptotic cell death [81]. The medium-chain ceramides form channels in the OMM, which in-crease permeability and enhance release of pro-apoptotic intermembrane space pro-teins, including cytochrome C [82]. Direct interaction between ceramides and VDAC permits cytochrome $C$ release, decreases mitochondrial membrane potential and dis-rupts ETC [83]. Moreover, ceramides inhibit insulinstimulated protein kinase $\mathrm{B}$ (PKB) phosphorylation by activating protein phosphatase

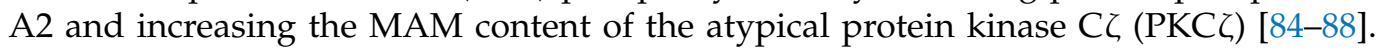
Chronic inhibition of ceramide synthesis by myriocin alleviates whole-body adiposity, decreases hepatic inflammation and steatosis, and improves indices of insulin sensitivity [89-91]. As one of the main sites for the biosynthesis of sphingolipids, an increased amount of ceramide at MAM negatively affects mitochondrial function and dynamic regulation, thus contributing to the development of insulin resistance and metabolic diseases (Figure 2).

\section{MAM}

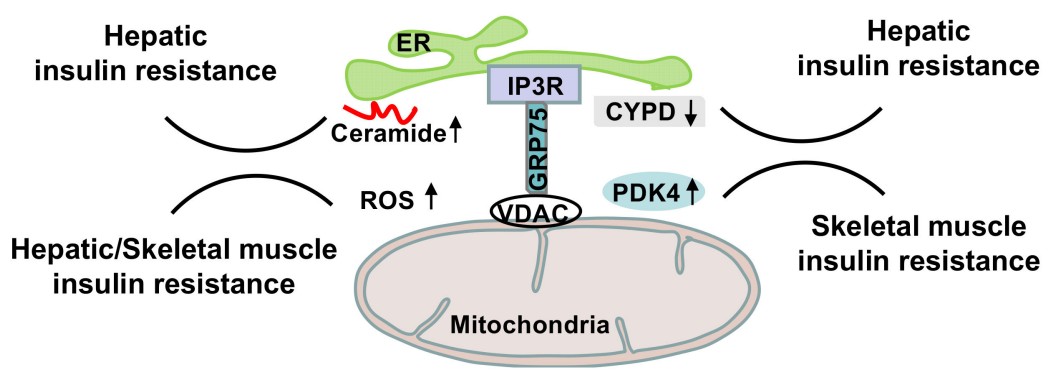

Figure 2. Regulation of MAM on insulin sensitivity.

\section{MAM and Interorganellar Calcium Flux}

Mitochondria do not store calcium under physiological conditions. Multiprotein tethering complexes exist at ER-mitochondria junctions to ensure calcium homeostasis for signal coupling [92]. The mitochondrial calcium uniporter (mtCU) located at the inner mitochondrial membrane (IMM) requires calcium levels $(10-20 \mu \mathrm{M})$ above the cytoplasmic peaks, which can be attained at nanodomains of MAM where IP3R or ryanodine recep- 
tors (RyR) calcium release channels (CRC) are located [93]. IP3R and RyR project from the surface of the ER membrane by 10-12 nm, thus limiting the minimum gap distance of MAM $[94,95]$. The close proximity $(\leq 100 \mathrm{~nm})$ of CRC, mtCU and VDAC allows the local exposure of high calcium flows [49]. However, engineered short linker tighter ERmitochondria contacts $(5 \mathrm{~nm}$ ) lead to smaller local calcium rise upon IP3R activation than the loose ER-mitochondria contacts via engineered long linkers $(15 \mathrm{~nm})$ [41]. GRP75 is critical for transferring calcium to mitochondria through the IP3R CRC [96]. GRP75 silencing attenuates calcium uptake by mitochon-dria by disrupting the functional coupling between IP3R and VDAC [49,97]. The IP3R-GRP75-VDAC complex also interacts with and is regulated by other proteins at MAM. The ER stress transducer IRE1 interacts with the IP3RGRP75-VDAC complex to stimulate mitochondrial respiration and ATP production [98]. The protein deglycase DJ-1 interacts with IP3R3-GRP75-VDAC to regulate MAM integrity and mitochondrial function [99]. The IP3R binding protein released with IP3 (IRBIT), a molecule that in-teracts with the IP3-binding pocket of IP3R, promotes MAM formation and facilitates calcium transfer to mitochondria [100]. A highly conserved OMM protein, FUN14 domain containing 1 (FUNDC1), interacts with IP3R to modulate the release of calci-um from ER into mitochondria. Disruption of the FUNDC1-IP3R interactions reduces calcium levels in mitochondria [101]. Alterations in the calcium flux at MAM lead to impaired insulin signaling (Figure 2). For example, cyclophilin D (CYPD), a mitochon-drial matrix protein that controls the opening of the permeability transition pore under stress conditions, interacts with the IP3R-GRP75-VDAC complex and facilitates interorganellar calcium exchange at MAM $[102,103]$. Disruption of MAM integrity by genetic or pharmacological inhibition of CYPD inhibits hepatic insulin signaling. Pyruvate dehydrogenase kinases 4 (PDK4), a mitochondrial enzyme suppressing the conversion of pyruvate to acetyl-CoA, interacts with the IP3R-GRP75-VDAC complex to cause mitochondrial calcium overload and dysfunction, thus dampening skeletal muscle insulin signaling [104].

Ryanodine receptors (RyRs, or feet) are located on the surface of the junctional sarcoplasmic reticulum (jSR) cisterna as two rows of ordered arrays. The RyRs face away from the mitochondrion and the minimum distance between them is $130 \pm 45 \mathrm{~nm}$ [105]. RyR localizes at MAM in the cardiac muscle [106]. In H9c2 cells, RyR increases calcium levels in mitochondrial matrix, leading to augmented NAD(P)H and ATP production $[107,108]$. RyRmediated mitochondrial transfer of calcium via VDAC reg-ulates oxidative metabolism in skeletal and cardiac muscles [109]. Triadin is a key component of the RyR CRC to control the calcium flow form ER [110,111]. In muscle cells, triadin binds to RyR and calsequestrin in a calcium-dependent manner to regu-late the ion channel complex on the membrane of SR. In addition, triadin is also asso-ciated with the MAM protein IP3R to regulate its function $[112,113]$. Thus, triadin may be essential for regulating the calcium transportation from ER to mitochondria through IP3R or RyR, indirectly regulating mitochondrial metabolism and energy production. Triadin also exhibits a dominant role in the modification of ER structure [114]. Triadin expression was shown to be associated with ER constriction and subsequent narrow ER tube formation. The OMM protein MFN2 regulates calcium levels by interacting with the sarco/endoplasmic reticulum calcium ATPase pump (SERCA), which actively transports calcium back into the ER [115]. Local SERCA activity at MAM controls the background calcium and filters out slow calcium release signals [116]. Of note are a number of activities in MAM that regulate the activity of SERCA. Phosphorylation of transmembrane chaperone calnexin (CNX) has been suggested to abolish the activity of SERCA [117]. Thioredoxin-related transmembrane protein 1 (TMX1) has also been suggested to interact with CNX to abolish the activity of SERCA while promoting ER-mitochondria contact formation [118,119]. Glutathione peroxidase (GPX8), an ER membrane protein and redox regulator resident at MAM, decreases the activity of SERCA [120]. The disruptions of calcium flow in or out from ER and mitochondria represent important processes involved in the development and progression of meta-bolic diseases [121]. 


\section{MAM and ROS Signaling}

In mitochondria, ROS is mainly produced from OXPHOS of ETC, with complexes I and II being the major culprits [122]. Under specific conditions and above certain thresholds, mitochondrial ROS may function as signaling factors or detrimental molecules to cellular processes. ROS can also be generated from the nanodomains and act as signaling messengers at MAM [123]. ROS originated from the cristae of mitochondria are enhanced by spikes in mitochondria calcium and regulated by a positive feedback loop [124] (Figure 1). Mitochondrial calcium aligns with ROS to regulate the opening of mitochondrial permeability transition pore (mPTP). The signaling of both calcium and ROS is determined according to their concentrations and spatial temporal restrictions [125]. A mild increase in ROS generated at MAM is necessary for cell survival under conditions of oxidative stress by decreasing ER-mitochondria calcium transfer [126,127]. However, excessive production of ROS and sustained calcium accumulation in mitochondria cause disruption of the mitochondrial membrane potential $(\Delta \Psi)$ and opening of the $\mathrm{MPTP}$, followed by controlled cell death [128]. At this stage, it is still not known how a refined production of ROS at MAM, in alliance with calcium, is achieved at the right time, right amount and right place to maintain cellular homeostasis.

Excessive calcium transfer via MAM induces the overproduction of mitochondrial ROS. For instance, augmented MAM formation results in increased transfer of calcium from the ER to mitochondria, and subsequent overproduction of ROS. Suppression of FUNDC1 and subsequent reduction in MAM formation ameliorate mitochondria ROS overproduction [129]. The different calcium channel regulators resident at MAM play key roles in modulating ROS production. For example, endoplasmic reticulum oxidoreductase 1 alpha $(E R O 1 \alpha)$ and endoplasmic reticulum protein 44 (ERp44) are ER oxidoreductases highly enriched in MAM [130]. ERO1 $\alpha$ causes ERp44 dissociation from IP3R by oxidizing the latter, which results in an exacerbated transfer of calcium from the ER to mitochondria, and subsequent ROS overproduction [131,132]. The increased ROS production further promotes ERO1 $\alpha$-dependent calcium signaling at MAM [133-135]. The disrupted-in-schizophrenia 1 (DISC1) dysfunction results in ab-errant mitochondria calcium accumulation following ROS overproduction, leading to mitochondrial abnormalities [136]. In skeletal muscles, disruption of RyR function promotes increased mitochondria ROS production [137]. In a murine model of aging, carbonylation and cysteine nitrosylation of RyR result in increased ROS production and impairment for muscle force generation. Rapamycin treatmentmediated RyR destabilization leads to increased mitochondrial matrix calcium levels, reduced mitochondrial membrane potential and enhanced ROS production [137].

\section{MAM in the Regulation of Insulin Sensitivity and Energy Homeostasis}

Many of the proteins at the interface between ER and mitochondria are involved in metabolic regulation and nutritional or hormonal signaling, highlighting the role of MAM in metabolic homeostasis [138]. Miscommunications between mitochondria and ER contribute to metabolic diseases such as insulin resistance and type 2 diabetes (T2D) $[104,110,139,140]$. While restoring ER-mitochondria tethering rescue the insulin sensitivity [141]. The MAM is essential for mitochondrial calcium signaling and ATP production, which is crucial for metabolic regulation in multiple organs [142].

The formation and structure of MAM are dynamically regulated by changes in the nutritional status [143]. The average length of MAM increases twice in the liver during starvation. Limited nutrients are associated with decreased mitochondria size, cristae density and respiratory capacity, but increased amount of MAM [144]. MFN2 is essential for these changes in response to the nutrition status. A proteolytic inactivation of optic atrophy 1 (Opa1), a major regulator of fusion and cristae architecture, accompanies these changes [144]. Thus, mitochondria adapt to nutrient depletion by coupling the molecular machineries that organize cristae architecture and MAM formation, which were previously thought to operate independently of each other [144]. Disruption of MAM by MFN2 depletion impairs starvation-induced autophagy and the formation of autophagosomes [145]. 
Glucose represents a main nutritional regulator of hepatic MAM integrity and mitochondrial dynamics and functions, through the pentose phosphate-protein phosphatase 2A (PP-PP2A) pathway [143]. PP2A regulates the release of calcium by IP3R at MAM [146]. High glucose levels reduce PP2A presence at MAM during refeeding in liver [97]. Altogether, MAM could act as a sensor to adapt nutritional transition in cell by regulating mitochondrial metabolism.

The integrity of MAM is necessary for glucose and insulin signaling to regulate metabolic adaptations to nutritional cues [97,147]. Indeed, several proteins associated with insulin signaling were found to locate at MAM interface, including the mammalian target of rapamycin complex 2 (mTORC2), PKB, the protein phosphatase 2A (PP2A), and the phosphatase and tensin homolog (PTEN) [148]. Chronic disruption of MAM by hyperglycemia participates in hepatic mitochondrial dysfunction associated with insulin resistance [143]. The MAM integrity was reported to be damaged by feeding in liver, which could be mimicked by augmenting blood glucose concentration [143]. In consistence, the in vitro experiment revealed that increasing glucose level inhibited the ER-mitochondria communication and $\mathrm{Ca}^{2+}$ exchange, suggesting a major role of glucose in regulating MAM integrity under status of high energy. At the molecular level, the pentose phosphate (PP)PP2A pathway was revealed to mediate the regulation of glucose on MAM integrity and subsequent mitochondrial respiration [143].

Hepatocyte insulin sensitivity has been shown to reduce in both genetically and high fat diet-induced obese and diabetic mice with reduced MAM content and function $[104,110,139]$, demonstrating the importance of MAM in hepatocyte insulin signaling. Antidiabetic medications in obese diabetic mice improve glucose tolerance and metabolism, increased MAM content in liver [97], reduced gluconeogenesis, and reduced ER stress. In the palmitate-induced insulin resistance model, palmitate has been demonstrated by several groups to disrupt MAM, induce ER stress, and reduce insulin signaling, which can be attenuated in hepatocytes by the overexpression of MFN2 in particular [104,139,140]. Another study in which ER-mitochondria tethering molecules MFN2 and GRP75 were silenced to disrupt MAM function showed that insulin signaling was impaired [97]. Disruption of the IP3R-GRP75-VDAC complex by CYPD knockdown also induced systemic insulin resistance and increased hepatic gluconeogenesis [97]. MAM content and function, although still a subject of contention has been widely shown to play a central role in hepatocyte insulin sensitivity and glucose homeostasis in obesity.

MAM content is found to be significantly lower in skeletal muscles of diet-induced and genetically obese mice as well as in obese diabetic humans. Tubbs and colleagues reported an early onset of reduction in MAM content following just 1-week of HFD feeding without insulin resistance, which only became evident after 16-weeks of HFD feeding, an indication that reduction of MAM content could contribute to insulin resistance but not the other way round [147]. A study by Tubbs et al. also showed that a significant disruption of the interactions between ER and mitochondria precedes mitochondrial dysfunction and insulin resistance in the myotubes of obese patients with or without T2D compared to healthy lean subjects. They also showed in both mice and human studies that, defective ER-mitochondria coupling is closely linked to impaired muscle insulin sensitivity $[147,149]$.

In pancreatic $\beta$-cells, acute glucose treatment stimulates ER-mitochondria interactions and calcium exchange, whereas disruption of MAM alters glucose-stimulated insulin secretion [150]. Chronic high glucose levels result in a reduced calcium store in ER but an enhanced calcium accumulation in mitochondria, accompanied by ER stress and altered mitochondrial respiration, collectively contributing to glucotoxicity-induced $\beta$-cell dysfunction [150]. In pancreatic $\beta$-cells of patients with type 2 diabetes, the number of IP3R-GRP75-VDAC complex is significantly decreased due to a re-duction in organelle interactions at MAM, thus leading to a defective glucose-stimulated insulin secretion [151]. ER calcium depletion and mitochondrial calcium overload were observed, which respectively led to ER stress and mitochondria dysfunction, and ultimately to impaired insulin secretion. 
In brown adipose tissue, inhibition of ERAD results in the formation of dysfunctional megamitochondria, due largely to increased MAM and ER perforation [139]. The sigma non-opioid intracellular receptor 1 (SigmaR1) is upregulated at MAM to mediate mitochondrial hyperfusion by promoting MFN2 oligomerization [139]. In white adipose tissue, CDGSH iron sulfur domain 2 (Cisd2) at MAM modulates mitochondrial calcium uptake. Loss of Cisd 2 causes metabolic defects in patients with Wolfram syn-drome by blunting mitochondrial biogenesis, adipogenesis, insulin-stimulated glucose uptake and the secretion of adiponectin $[140,152]$. In white adipose tissues, adrenergic stimulation activates PDK4 [153] which has recently been implicated in MAM formation [104].

\section{Conclusions}

The importance of the crosstalk between the ER and mitochondria in regulating organelle homeostasis and cell function cannot be over emphasized. The MAM per se promise to be an important hub where both insulin and nutrient signaling are tightly regulated to ensure metabolic homeostasis. However, the precise relationship between the miscommunications of the two organelles and the development of metabolic diseases remains to be elucidated. It will also be interesting to explore this relationship in humans. Future studies should be directed towards identifying agents that can improve the integrity, flexibility and function of MAM, as they may represent a new generation of therapeutics for prevention and treatment of metabolic diseases.

Author Contributions: Conceptualization, Y.W.; writing-original draft preparation, P.Z., D.K., Y.Z. and Y.W.; writing-review and editing, Y.W. All authors have read and agreed to the published version of the manuscript.

Funding: This research was funded by the grants from the General Research Funds (17153016) and Collaborative Research Funds (C7037-17W) of Research Grant Council, and the Areas of Excellence Scheme (AoE/M-707/18) of University Grants Committee, Hong Kong.

Conflicts of Interest: The authors declare no conflict of interest.

\section{References}

1. Spinelli, J.B.; Haigis, M.C. The multifaceted contributions of mitochondria to cellular metabolism. Nat. Cell Biol. 2018, 20, 745-754. [CrossRef] [PubMed]

2. Bhatti, J.S.; Bhatti, G.K.; Reddy, P.H. Mitochondrial dysfunction and oxidative stress in metabolic disorders-A step towards mitochondria based therapeutic strategies. Biochim. Biophys. Acta Mol. Basis Dis. 2017, 1863, 1066-1077. [CrossRef] [PubMed]

3. Bock, F.J.; Tait, S.W. Mitochondria as multifaceted regulators of cell death. Nat. Rev. Mol. Cell Biol. 2020, 21, 85-100. [CrossRef]

4. Javadov, S.; Kozlov, A.V.; Camara, A.K. Mitochondria in health and diseases. Cells 2020, 9, 1177. [CrossRef] [PubMed]

5. Kummer, E.; Ban, N. Mechanisms and regulation of protein synthesis in mitochondria. Nat. Rev. Mol. Cell Biol. 2021, 22, 1-19. [CrossRef]

6. Haroon, S.; Vermulst, M. Linking mitochondrial dynamics to mitochondrial protein quality control. Curr. Opin. Genet. Dev. 2016, 38, 68-74. [CrossRef]

7. Ni, H.-M.; Williams, J.A.; Ding, W.-X. Mitochondrial dynamics and mitochondrial quality control. Redox Biol. 2015, 4, 6-13. [CrossRef]

8. Ristow, M.; Zarse, K. How increased oxidative stress promotes longevity and metabolic health: The concept of mitochondrial hormesis (mitohormesis). Exp. Gerontol. 2010, 45, 410-418. [CrossRef]

9. Ristow, M.; Schmeisser, K. Mitohormesis: Promoting health and lifespan by increased levels of reactive oxygen species (ROS). Dose Response 2014, 12, 13-035. [CrossRef]

10. Arruda, A.P.; Hotamisligil, G.S. Calcium homeostasis and organelle function in the pathogenesis of obesity and diabetes. Cell Metab. 2015, 22, 381-397. [CrossRef]

11. Fu, S.; Watkins, S.M.; Hotamisligil, G.S. The role of endoplasmic reticulum in hepatic lipid homeostasis and stress signaling. Cell Metab. 2012, 15, 623-634. [CrossRef]

12. Hotamisligil, G.S. Endoplasmic reticulum stress and the inflammatory basis of metabolic disease. Cell 2010, 140, 900-917. [CrossRef]

13. Lemmer, I.L.; Willemsen, N.; Hilal, N.; Bartelt, A. A guide to understanding endoplasmic reticulum stress in metabolic disorders. Mol. Metab. 2021, 47, 101169. [CrossRef] [PubMed]

14. Walter, P.; Ron, D. The unfolded protein response: From stress pathway to homeostatic regulation. Science 2011, 334, 1081-1086. [CrossRef] [PubMed] 
15. Wu, X.; Rapoport, T.A. Mechanistic insights into ER-associated protein degradation. Curr. Opin. Cell Biol. 2018, 53, 22-28. [CrossRef] [PubMed]

16. Maamoun, H.; Abdelsalam, S.S.; Zeidan, A.; Korashy, H.M.; Agouni, A. Endoplasmic reticulum stress: A critical molecular driver of endothelial dysfunction and cardiovascular disturbances associated with diabetes. Int. J. Mol. Sci. 2019, 20, 1658. [CrossRef] [PubMed]

17. Ramos-Lopez, O.; Riezu-Boj, J.I.; Milagro, F.I.; Moreno-Aliaga, M.J.; Martinez, J.A.; MENA, p. Endoplasmic reticulum stress epigenetics is related to adiposity, dyslipidemia, and insulin resistance. Adipocyte 2018, 7, 137-142. [CrossRef] [PubMed]

18. Özcan, U.; Cao, Q.; Yilmaz, E.; Lee, A.-H.; Iwakoshi, N.N.; Özdelen, E.; Tuncman, G.; Görgün, C.; Glimcher, L.H.; Hotamisligil, G.S. Endoplasmic reticulum stress links obesity, insulin action, and type 2 diabetes. Science 2004, 306, 457-461. [CrossRef]

19. Engin, F. ER stress and development of type 1 diabetes. J. Investig. Med. Off. Publ. Am. Fed. Clin. Res. 2016, 64, 2-6. [CrossRef] [PubMed]

20. Csordás, G.; Weaver, D.; Hajnóczky, G. Endoplasmic reticulum-mitochondrial contactology: Structure and signaling functions. Trends Cell Biol. 2018, 28, 523-540. [CrossRef] [PubMed]

21. Jackisch, L.; Murphy, A.M.; Kumar, S.; Randeva, H.; Tripathi, G.; McTernan, P.G. Tunicamycin-induced Endoplasmic Reticulum stress mediates mitochondrial dysfunction in human adipocytes. J. Clin. Endocrinol. Metab. 2020, 105, 2905-2918. [CrossRef]

22. Lim, J.H.; Lee, H.J.; Jung, M.H.; Song, J. Coupling mitochondrial dysfunction to endoplasmic reticulum stress response: A molecular mechanism leading to hepatic insulin resistance. Cell. Signal. 2009, 21, 169-177. [CrossRef]

23. Biczo, G.; Vegh, E.T.; Shalbueva, N.; Mareninova, O.A.; Elperin, J.; Lotshaw, E.; Gretler, S.; Lugea, A.; Malla, S.R.; Dawson, D. Mitochondrial dysfunction, through impaired autophagy, leads to endoplasmic reticulum stress, deregulated lipid metabolism, and pancreatitis in animal models. Gastroenterology 2018, 154, 689-703. [CrossRef] [PubMed]

24. Rieusset, J. Contribution of mitochondria and endoplasmic reticulum dysfunction in insulin resistance: Distinct or interrelated roles? Diabetes Metab. 2015, 41, 358-368. [CrossRef] [PubMed]

25. Herrera-Cruz, M.S.; Simmen, T. Over six decades of discovery and characterization of the architecture at mitochondria-associated membranes (MAMs). Organelle Contact Sites 2017, 13-31. [CrossRef]

26. Scorrano, L.; De Matteis, M.A.; Emr, S.; Giordano, F.; Hajnóczky, G.; Kornmann, B.; Lackner, L.L.; Levine, T.P.; Pellegrini, L.; Reinisch, K. Coming together to define membrane contact sites. Nat. Commun. 2019, 10, 1-11. [CrossRef]

27. Area-Gomez, E. Assessing the function of mitochondria-associated ER membranes. Methods Enzymol. 2014, 547, 181-197. [CrossRef]

28. Friedman, J.R.; Lackner, L.L.; West, M.; DiBenedetto, J.R.; Nunnari, J.; Voeltz, G.K. ER tubules mark sites of mitochondrial division. Science 2011, 334, 358-362. [CrossRef] [PubMed]

29. Murley, A.; Lackner, L.L.; Osman, C.; West, M.; Voeltz, G.K.; Walter, P.; Nunnari, J. ER-associated mitochondrial division links the distribution of mitochondria and mitochondrial DNA in yeast. Elife 2013, 2, e00422. [CrossRef] [PubMed]

30. Lewis, S.C.; Uchiyama, L.F.; Nunnari, J. ER-mitochondria contacts couple mtDNA synthesis with mitochondrial division in human cells. Science 2016, 353, aaf5549. [CrossRef] [PubMed]

31. Copeland, D.; Dalton, A. An association between mitochondria and the endoplasmic reticulum in cells of the pseudobranch gland of a teleost. J. Cell Biol. 1959, 5, 393-396. [CrossRef]

32. Bernhard, W.; Rouiller, C. Close topographical relationship between mitochondria and ergastoplasm of liver cells in a definite phase of cellular activity. J. Cell Biol. 1956, 2, 73-78. [CrossRef]

33. Shiao, Y.-J.; Lupo, G.; Vance, J.E. Evidence that phosphatidylserine is imported into mitochondria via a mitochondria-associated membrane and that the majority of mitochondrial phosphatidylethanolamine is derived from decarboxylation of phosphatidylserine. J. Biol. Chem. 1995, 270, 11190-11198. [CrossRef] [PubMed]

34. Vance, J.E. Phospholipid synthesis in a membrane fraction associated with mitochondria. J. Biol. Chem. 1990, 265, 7248-7256. [CrossRef]

35. Zinser, E.; Sperka-Gottlieb, C.; Fasch, E.-V.; Kohlwein, S.D.; Paltauf, F.; Daum, G. Phospholipid synthesis and lipid composition of subcellular membranes in the unicellular eukaryote Saccharomyces cerevisiae. J. Bacteriol. 1991, 173, 2026-2034. [CrossRef] [PubMed]

36. Rusinol, A.E.; Cui, Z.; Chen, M.H.; Vance, J.E. A unique mitochondria-associated membrane fraction from rat liver has a high capacity for lipid synthesis and contains pre-Golgi secretory proteins including nascent lipoproteins. J. Biol. Chem. 1994, 269, 27494-27502. [CrossRef]

37. Soltys, S.M.; Kashani, J.H.; Dandoy, A.C.; Vaidya, A.F.; Reid, J.C. Comorbidity for disruptive behavior disorders in psychiatrically hospitalized children. Child Psychiatry Hum. Dev. 1992, 23, 87-98. [CrossRef] [PubMed]

38. Csordás, G.r.; Renken, C.; Várnai, P.; Walter, L.; Weaver, D.; Buttle, K.F.; Balla, T.; Mannella, C.A.; Hajnóczky, G.r. Structural and functional features and significance of the physical linkage between ER and mitochondria. J. Cell Biol. 2006, 174, 915-921. [CrossRef]

39. Wang, P.T.; Garcin, P.O.; Fu, M.; Masoudi, M.; St-Pierre, P.; Panté, N.; Nabi, I.R. Distinct mechanisms controlling rough and smooth endoplasmic reticulum contacts with mitochondria. J. Cell Sci. 2015, 128, 2759-2765. [CrossRef]

40. Giacomello, M.; Pellegrini, L. The coming of age of the mitochondria-ER contact: A matter of thickness. Cell Death Differ. 2016, 23, 1417-1427. [CrossRef] 
41. Csordás, G.; Várnai, P.; Golenár, T.; Roy, S.; Purkins, G.; Schneider, T.G.; Balla, T.; Hajnóczky, G. Imaging interorganelle contacts and local calcium dynamics at the ER-mitochondrial interface. Mol. Cell 2010, 39, 121-132. [CrossRef]

42. Lee, S.; Min, K.-T. The interface between ER and mitochondria: Molecular compositions and functions. Mol. Cells 2018, 41, 1000. [CrossRef]

43. Poston, C.N.; Krishnan, S.C.; Bazemore-Walker, C.R. In-depth proteomic analysis of mammalian mitochondria-associated membranes (MAM). J. Proteom. 2013, 79, 219-230. [CrossRef] [PubMed]

44. Wang, X.; Wen, Y.; Dong, J.; Cao, C.; Yuan, S. Systematic In-Depth Proteomic Analysis of Mitochondria-Associated Endoplasmic Reticulum Membranes in Mouse and Human Testes. Proteomics 2018, 18, e1700478. [CrossRef] [PubMed]

45. Baudier, J. ATAD3 proteins: Brokers of a mitochondria-endoplasmic reticulum connection in mammalian cells. Biol. Rev. Camb. Philos. Soc. 2018, 93, 827-844. [CrossRef]

46. De Vos, K.J.; Morotz, G.M.; Stoica, R.; Tudor, E.L.; Lau, K.-F.; Ackerley, S.; Warley, A.; Shaw, C.E.; Miller, C.C. VAPB interacts with the mitochondrial protein PTPIP51 to regulate calcium homeostasis. Hum. Mol. Genet. 2012, 21, 1299-1311. [CrossRef] [PubMed]

47. Gomez-Suaga, P.; Paillusson, S.; Stoica, R.; Noble, W.; Hanger, D.P.; Miller, C.C. The ER-mitochondria tethering complex VAPB-PTPIP51 regulates autophagy. Curr. Biol. 2017, 27, 371-385. [CrossRef] [PubMed]

48. Stoica, R.; De Vos, K.J.; Paillusson, S.; Mueller, S.; Sancho, R.M.; Lau, K.-F.; Vizcay-Barrena, G.; Lin, W.-L.; Xu, Y.-F.; Lewis, J. ER-mitochondria associations are regulated by the VAPB-PTPIP51 interaction and are disrupted by ALS/FTD-associated TDP-43. Nat. Commun. 2014, 5, 1-12. [CrossRef]

49. Szabadkai, G.; Bianchi, K.; Várnai, P.; De Stefani, D.; Wieckowski, M.R.; Cavagna, D.; Nagy, A.I.; Balla, T.; Rizzuto, R. Chaperonemediated coupling of endoplasmic reticulum and mitochondrial $\mathrm{Ca}^{2+}$ channels. J. Cell Biol. 2006, 175, 901-911. [CrossRef]

50. Rosencrans, W.M.; Rajendran, M.; Bezrukov, S.M.; Rostovtseva, T.K. VDAC regulation of mitochondrial calcium flux: From channel biophysics to disease. Cell Calcium 2021, 94, 102356. [CrossRef]

51. Cárdenas, C.; Miller, R.A.; Smith, I.; Bui, T.; Molgó, J.; Müller, M.; Vais, H.; Cheung, K.-H.; Yang, J.; Parker, I. Essential regulation of cell bioenergetics by constitutive InsP3 receptor $\mathrm{Ca}^{2+}$ transfer to mitochondria. Cell 2010, 142, 270-283. [CrossRef]

52. Adachi, Y.; Kato, T.; Yamada, T.; Murata, D.; Arai, K.; Stahelin, R.V.; Chan, D.C.; Iijima, M.; Sesaki, H. Drp1 Tubulates the ER in a GTPase-Independent Manner. Mol. Cell 2020, 80, 621-632.e626. [CrossRef] [PubMed]

53. De Brito, O.M.; Scorrano, L. Mitofusin 2 tethers endoplasmic reticulum to mitochondria. Nature 2008, 456, 605-610. [CrossRef] [PubMed]

54. Naon, D.; Zaninello, M.; Giacomello, M.; Varanita, T.; Grespi, F.; Lakshminaranayan, S.; Serafini, A.; Semenzato, M.; Herkenne, S.; Hernández-Alvarez, M.I. Critical reappraisal confirms that Mitofusin 2 is an endoplasmic reticulum-mitochondria tether. Proc. Natl. Acad. Sci. USA 2016, 113, 11249-11254. [CrossRef]

55. Sugiura, A.; Nagashima, S.; Tokuyama, T.; Amo, T.; Matsuki, Y.; Ishido, S.; Kudo, Y.; McBride, H.M.; Fukuda, T.; Matsushita, N. MITOL regulates endoplasmic reticulum-mitochondria contacts via Mitofusin2. Mol. Cell 2013, 51, 20-34. [CrossRef]

56. McLelland, G.-L.; Goiran, T.; Yi, W.; Dorval, G.; Chen, C.X.; Lauinger, N.D.; Krahn, A.I.; Valimehr, S.; Rakovic, A.; Rouiller, I. Mfn2 ubiquitination by PINK1/parkin gates the p97-dependent release of ER from mitochondria to drive mitophagy. Elife 2018, 7, e32866. [CrossRef]

57. Basso, V.; Marchesan, E.; Peggion, C.; Chakraborty, J.; von Stockum, S.; Giacomello, M.; Ottolini, D.; Debattisti, V.; Caicci, F.; Tasca, E.; et al. Regulation of ER-mitochondria contacts by Parkin via Mfn2. Pharmacol. Res. 2018, 138, 43-56. [CrossRef]

58. Filadi, R.; Greotti, E.; Turacchio, G.; Luini, A.; Pozzan, T.; Pizzo, P. Presenilin 2 Modulates Endoplasmic Reticulum-Mitochondria Coupling by Tuning the Antagonistic Effect of Mitofusin 2. Cell Rep. 2016, 15, 2226-2238. [CrossRef]

59. Loson, O.C.; Song, Z.; Chen, H.; Chan, D.C. Fis1, Mff, MiD49, and MiD51 mediate Drp1 recruitment in mitochondrial fission. Mol. Biol. Cell 2013, 24, 659-667. [CrossRef]

60. Iwasawa, R.; Mahul-Mellier, A.L.; Datler, C.; Pazarentzos, E.; Grimm, S. Fis1 and Bap31 bridge the mitochondria-ER interface to establish a platform for apoptosis induction. EMBO J. 2011, 30, 556-568. [CrossRef] [PubMed]

61. Namba, T. BAP31 regulates mitochondrial function via interaction with Tom40 within ER-mitochondria contact sites. Sci. Adv. 2019, 5, eaaw1386. [CrossRef]

62. Vance, J.E. MAM (mitochondria-associated membranes) in mammalian cells: Lipids and beyond. Biochim. Biophys. Acta 2014, 1841, 595-609. [CrossRef]

63. Prinz, W.A. Bridging the gap: Membrane contact sites in signaling, metabolism, and organelle dynamics. J. Cell Biol. 2014, 205, 759-769. [CrossRef]

64. Cui, Z.; Vance, J.E.; Chen, M.H.; Voelker, D.R.; Vance, D.E. Cloning and expression of a novel phosphatidylethanolamine $\mathrm{N}$-methyltransferase. A specific biochemical and cytological marker for a unique membrane fraction in rat liver. J. Biol. Chem. 1993, 268, 16655-16663. [CrossRef]

65. Petrungaro, C.; Kornmann, B. Lipid exchange at ER-mitochondria contact sites: A puzzle falling into place with quite a few pieces missing. Curr. Opin. Cell Biol. 2019, 57, 71-76. [CrossRef]

66. Kornmann, B.; Currie, E.; Collins, S.R.; Schuldiner, M.; Nunnari, J.; Weissman, J.S.; Walter, P. An ER-mitochondria tethering complex revealed by a synthetic biology screen. Science 2009, 325, 477-481. [CrossRef]

67. Elbaz-Alon, Y.; Guo, Y.; Segev, N.; Harel, M.; Quinnell, D.E.; Geiger, T.; Avinoam, O.; Li, D.; Nunnari, J. PDZD8 interacts with Protrudin and Rab7 at ER-late endosome membrane contact sites associated with mitochondria. Nat. Commun. 2020, 11, 1-14. [CrossRef] [PubMed] 
68. Kulinski, A.; Rustaeus, S.; Vance, J.E. Microsomal triacylglycerol transfer protein is required for lumenal accretion of triacylglycerol not associated with ApoB, as well as for ApoB lipidation. J. Biol. Chem. 2002, 277, 31516-31525. [CrossRef] [PubMed]

69. AhYoung, A.P.; Jiang, J.; Zhang, J.; Khoi Dang, X.; Loo, J.A.; Zhou, Z.H.; Egea, P.F. Conserved SMP domains of the ERMES complex bind phospholipids and mediate tether assembly. Proc. Natl. Acad. Sci. USA 2015, 112, E3179-E3188. [CrossRef]

70. Hirabayashi, Y.; Kwon, S.K.; Paek, H.; Pernice, W.M.; Paul, M.A.; Lee, J.; Erfani, P.; Raczkowski, A.; Petrey, D.S.; Pon, L.A.; et al. ER-mitochondria tethering by PDZD8 regulates $\mathrm{Ca}(2+)$ dynamics in mammalian neurons. Science 2017, 358, 623-630. [CrossRef]

71. Anastasia, I.; Ilacqua, N.; Raimondi, A.; Lemieux, P.; Ghandehari-Alavijeh, R.; Faure, G.; Mekhedov, S.L.; Williams, K.J.; Caicci, F.; Valle, G.; et al. Mitochondria-rough-ER contacts in the liver regulate systemic lipid homeostasis. Cell Rep. $2021,34,108873$. [CrossRef]

72. Bartke, N.; Hannun, Y.A. Bioactive sphingolipids: Metabolism and function. J. Lipid Res. 2009, 50, S91-S96. [CrossRef] [PubMed]

73. Hannun, Y.A.; Obeid, L.M. Sphingolipids and their metabolism in physiology and disease. Nat. Rev. Mol. Cell Biol. 2018, 19, 175. [CrossRef] [PubMed]

74. Trayssac, M.; Hannun, Y.A.; Obeid, L.M. Role of sphingolipids in senescence: Implication in aging and age-related diseases. J. Clin. Investig. 2018, 128, 2702-2712. [CrossRef] [PubMed]

75. Breslow, D.K. Sphingolipid homeostasis in the endoplasmic reticulum and beyond. Cold Spring Harb. Perspect. Biol. 2013, 5, a013326. [CrossRef]

76. Bionda, C.; Portoukalian, J.; Schmitt, D.; Rodriguez-Lafrasse, C.; Ardail, D. Subcellular compartmentalization of ceramide metabolism: MAM (mitochondria-associated membrane) and/or mitochondria? Biochem. J. 2004, 382, 527-533. [CrossRef]

77. Stiban, J.; Caputo, L.; Colombini, M. Ceramide synthesis in the endoplasmic reticulum can permeabilize mitochondria to proapoptotic proteins. J. Lipid Res. 2008, 49, 625-634. [CrossRef]

78. Roszczyc-Owsiejczuk, K.; Zabielski, P. Sphingolipids as a Culprit of Mitochondrial Dysfunction in Insulin Resistance and Type 2 Diabetes. Front. Endocrinol. 2021, 12, 143. [CrossRef] [PubMed]

79. Perreault, L.; Newsom, S.A.; Strauss, A.; Kerege, A.; Kahn, D.E.; Harrison, K.A.; Snell-Bergeon, J.K.; Nemkov, T.; D’ Alessandro, A.; Jackman, M.R. Intracellular localization of diacylglycerols and sphingolipids influences insulin sensitivity and mitochondrial function in human skeletal muscle. JCI Insight 2018, 3. [CrossRef]

80. Gudz, T.I.; Tserng, K.-Y.; Hoppel, C.L. Direct inhibition of mitochondrial respiratory chain complex III by cell-permeable ceramide. J. Biol. Chem. 1997, 272, 24154-24158. [CrossRef]

81. Jain, A.; Beutel, O.; Ebell, K.; Korneev, S.; Holthuis, J.C. Diverting CERT-mediated ceramide transport to mitochondria triggers Bax-dependent apoptosis. J. Cell Sci. 2017, 130, 360-371. [CrossRef] [PubMed]

82. Tait, S.W.; Green, D.R. Mitochondrial regulation of cell death. Cold Spring Harb. Perspect. Biol. 2013, 5. [CrossRef] [PubMed]

83. Dadsena, S.; Bockelmann, S.; Mina, J.G.; Hassan, D.G.; Korneev, S.; Razzera, G.; Jahn, H.; Niekamp, P.; Müller, D.; Schneider, M. Ceramides bind VDAC2 to trigger mitochondrial apoptosis. Nat. Commun. 2019, 10, 1-12. [CrossRef] [PubMed]

84. Chavez, J.A.; Knotts, T.A.; Wang, L.-P.; Li, G.; Dobrowsky, R.T.; Florant, G.L.; Summers, S.A. A role for ceramide, but not diacylglycerol, in the antagonism of insulin signal transduction by saturated fatty acids. J. Biol. Chem. 2003, 278, 10297-10303. [CrossRef] [PubMed]

85. Hajduch, E.; Turban, S.; Le Liepvre, X.; Le Lay, S.; Lipina, C.; Dimopoulos, N.; Dugail, I.; Hundal, H.S. Targeting of PKC $\zeta$ and PKB to caveolin-enriched microdomains represents a crucial step underpinning the disruption in PKB-directed signalling by ceramide. Biochem. J. 2008, 410, 369-379. [CrossRef]

86. Mahfouz, R.; Khoury, R.; Blachnio-Zabielska, A.; Turban, S.; Loiseau, N.; Lipina, C.; Stretton, C.; Bourron, O.; Ferré, P.; Foufelle, F. Characterising the inhibitory actions of ceramide upon insulin signaling in different skeletal muscle cell models: A mechanistic insight. PLoS ONE 2014, 9, e101865. [CrossRef]

87. Powell, D.J.; Hajduch, E.; Kular, G.; Hundal, H.S. Ceramide disables 3-phosphoinositide binding to the pleckstrin homology

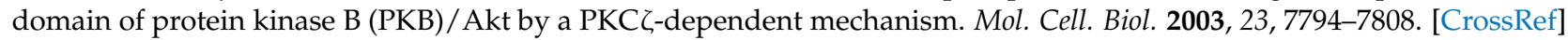

88. Schubert, K.M.; Scheid, M.P.; Duronio, V. Ceramide inhibits protein kinase B/Akt by promoting dephosphorylation of serine 473. J. Biol. Chem. 2000, 275, 13330-13335. [CrossRef]

89. Chaurasia, B.; Ying, L.; Talbot, C.L.; Maschek, J.A.; Cox, J.; Schuchman, E.H.; Hirabayashi, Y.; Holland, W.L.; Summers, S.A. Ceramides are necessary and sufficient for diet-induced impairment of thermogenic adipocytes. Mol. Metab. 2021, 45, 101145. [CrossRef]

90. Jiang, M.; Li, C.; Liu, Q.; Wang, A.; Lei, M. Inhibiting Ceramide Synthesis Attenuates Hepatic Steatosis and Fibrosis in Rats With Non-alcoholic Fatty Liver Disease. Front. Endocrinol. 2019, 10, 665. [CrossRef]

91. Yang, G.; Badeanlou, L.; Bielawski, J.; Roberts, A.J.; Hannun, Y.A.; Samad, F. Central role of ceramide biosynthesis in body weight regulation, energy metabolism, and the metabolic syndrome. Am. J. Physiol. Endocrinol. Metab. 2009, 297, E211-E224. [CrossRef]

92. Lee, K.-S.; Huh, S.; Lee, S.; Wu, Z.; Kim, A.-K.; Kang, H.-Y.; Lu, B. Altered ER-mitochondria contact impacts mitochondria calcium homeostasis and contributes to neurodegeneration in vivo in disease models. Proc. Natl. Acad. Sci. USA 2018, 115, E8844-E8853. [CrossRef]

93. De Stefani, D.; Rizzuto, R.; Pozzan, T. Enjoy the Trip: Calcium in Mitochondria Back and Forth. Annu. Rev. Biochem. 2016, 85, 161-192. [CrossRef]

94. Fleischer, S. Personal recollections on the discovery of the ryanodine receptors of muscle. Biochem. Biophys. Res. Commun. 2008, 369, 195-207. [CrossRef] 
95. Ludtke, S.J.; Tran, T.P.; Ngo, Q.T.; Moiseenkova-Bell, V.Y.; Chiu, W.; Serysheva, I.I. Flexible architecture of IP3R1 by Cryo-EM. Structure 2011, 19, 1192-1199. [CrossRef]

96. Honrath, B.; Metz, I.; Bendridi, N.; Rieusset, J.; Culmsee, C.; Dolga, A.M. Glucose-regulated protein 75 determines ERmitochondrial coupling and sensitivity to oxidative stress in neuronal cells. Cell Death Discov. 2017, 3, 17076. [CrossRef] [PubMed]

97. Tubbs, E.; Theurey, P.; Vial, G.; Bendridi, N.; Bravard, A.; Chauvin, M.-A.; Ji-Cao, J.; Zoulim, F.; Bartosch, B.; Ovize, M. Mitochondria-associated endoplasmic reticulum membrane (MAM) integrity is required for insulin signaling and is implicated in hepatic insulin resistance. Diabetes 2014, 63, 3279-3294. [CrossRef] [PubMed]

98. Carreras-Sureda, A.; Jaña, F.; Urra, H.; Durand, S.; Mortenson, D.E.; Sagredo, A.; Bustos, G.; Hazari, Y.; Ramos-Fernández, E.; Sassano, M.L. Non-canonical function of IRE1 $\alpha$ determines mitochondria-associated endoplasmic reticulum composition to control calcium transfer and bioenergetics. Nat. Cell Biol. 2019, 21, 755-767. [CrossRef]

99. Liu, Y.; Ma, X.; Fujioka, H.; Liu, J.; Chen, S.; Zhu, X. DJ-1 regulates the integrity and function of ER-mitochondria association through interaction with IP3R3-Grp75-VDAC1. Proc. Natl. Acad. Sci. USA 2019, 116, 25322-25328. [CrossRef]

100. Bonneau, B.; Ando, H.; Kawaai, K.; Hirose, M.; Takahashi-Iwanaga, H.; Mikoshiba, K. IRBIT controls apoptosis by interacting with the Bcl-2 homolog, Bcl2110, and by promoting ER-mitochondria contact. Elife 2016, 5. [CrossRef]

101. Wu, S.; Lu, Q.; Wang, Q.; Ding, Y.; Ma, Z.; Mao, X.; Huang, K.; Xie, Z.; Zou, M.H. Binding of FUN14 Domain Containing 1 With Inositol 1,4,5-Trisphosphate Receptor in Mitochondria-Associated Endoplasmic Reticulum Membranes Maintains Mitochondrial Dynamics and Function in Hearts in Vivo. Circulation 2017, 136, 2248-2266. [CrossRef] [PubMed]

102. Paillard, M.; Tubbs, E.; Thiebaut, P.-A.; Gomez, L.; Fauconnier, J.; Crola Da Silva, C.; Teixeira, G.; Mewton, N.; Belaidi, E.; Durand, A. Depressing mitochondria-reticulum interactions protects cardiomyocytes from lethal hypoxia-reoxygenation injury. Circulation 2013, 128, 1555-1565. [CrossRef] [PubMed]

103. Rieusset, J.; Fauconnier, J.; Paillard, M.; Belaidi, E.; Tubbs, E.; Chauvin, M.-A.; Durand, A.; Bravard, A.; Teixeira, G.; Bartosch, B. Disruption of calcium transfer from ER to mitochondria links alterations of mitochondria-associated ER membrane integrity to hepatic insulin resistance. Diabetologia 2016, 59, 614-623. [CrossRef] [PubMed]

104. Thoudam, T.; Ha, C.-M.; Leem, J.; Chanda, D.; Park, J.-S.; Kim, H.-J.; Jeon, J.-H.; Choi, Y.-K.; Liangpunsakul, S.; Huh, Y.H. PDK4 augments ER-mitochondria contact to dampen skeletal muscle insulin signaling during obesity. Diabetes 2019, 68, 571-586. [CrossRef]

105. Boncompagni, S.; Rossi, A.E.; Micaroni, M.; Beznoussenko, G.V.; Polishchuk, R.S.; Dirksen, R.T.; Protasi, F. Mitochondria are linked to calcium stores in striated muscle by developmentally regulated tethering structures. Mol. Biol. Cell 2009, 20, 1058-1067. [CrossRef]

106. Chen, Y.; Csordas, G.; Jowdy, C.; Schneider, T.G.; Csordas, N.; Wang, W.; Liu, Y.; Kohlhaas, M.; Meiser, M.; Bergem, S.; et al. Mitofusin 2-containing mitochondrial-reticular microdomains direct rapid cardiomyocyte bioenergetic responses via interorganelle $\mathrm{Ca}(2+)$ crosstalk. Circ. Res. 2012, 111, 863-875. [CrossRef]

107. Pacher, P.; Csordas, P.; Schneider, T.; Hajnoczky, G. Quantification of calcium signal transmission from sarco-endoplasmic reticulum to the mitochondria. J. Physiol. 2000, 529, 553-564. [CrossRef]

108. Szalai, G.; Csordás, G.; Hantash, B.M.; Thomas, A.P.; Hajnóczky, G. Calcium signal transmission between ryanodine receptors and mitochondria. J. Biol. Chem. 2000, 275, 15305-15313. [CrossRef]

109. Rapizzi, E.; Pinton, P.; Szabadkai, G.; Wieckowski, M.R.; Vandecasteele, G.; Baird, G.; Tuft, R.A.; Fogarty, K.E.; Rizzuto, R. Recombinant expression of the voltage-dependent anion channel enhances the transfer of $\mathrm{Ca}^{2+}$ microdomains to mitochondria. J. Cell Biol. 2002, 159, 613-624. [CrossRef]

110. Dulhunty, A.F.; Wei-LaPierre, L.; Casarotto, M.G.; Beard, N.A. Core skeletal muscle ryanodine receptor calcium release complex. Clin. Exp. Pharmacol. Physiol. 2017, 44,3-12. [CrossRef]

111. Marty, I. Triadin regulation of the ryanodine receptor complex. J. Physiol. 2015, 593, 3261-3266. [CrossRef]

112. Ríos, E.; Györke, S. Calsequestrin, triadin and more: The molecules that modulate calcium release in cardiac and skeletal muscle. J. Physiol. 2009, 587, 3069. [CrossRef]

113. Prole, D.L.; Taylor, C.W. Inositol 1, 4, 5-trisphosphate receptors and their protein partners as signalling hubs. J. Physiol. 2016, 594, 2849-2866. [CrossRef] [PubMed]

114. Fourest-Lieuvin, A.; Rendu, J.; Osseni, A.; Pernet-Gallay, K.; Rossi, D.; Oddoux, S.; Brocard, J.; Sorrentino, V.; Marty, I.; Fauré, J. Role of triadin in the organization of reticulum membrane at the muscle triad. J. Cell Sci. 2012, 125, 3443-3453. [CrossRef] [PubMed]

115. Filadi, R.; Leal, N.S.; Schreiner, B.; Rossi, A.; Dentoni, G.; Pinho, C.M.; Wiehager, B.; Cieri, D.; Calì, T.; Pizzo, P. TOM70 sustains cell bioenergetics by promoting IP3R3-mediated ER to mitochondria Ca ${ }^{2+}$ transfer. Curr. Biol. 2018, 28, 369-382.e366. [CrossRef]

116. Csordas, G.; Hajnoczky, G. Sorting of calcium signals at the junctions of endoplasmic reticulum and mitochondria. Cell Calcium 2001, 29, 249-262. [CrossRef] [PubMed]

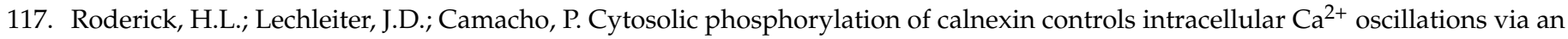
interaction with SERCA2b. J. Cell Biol. 2000, 149, 1235-1248. [CrossRef] [PubMed]

118. Raturi, A.; Gutiérrez, T.; Ortiz-Sandoval, C.; Ruangkittisakul, A.; Herrera-Cruz, M.S.; Rockley, J.P.; Gesson, K.; Ourdev, D.; Lou,

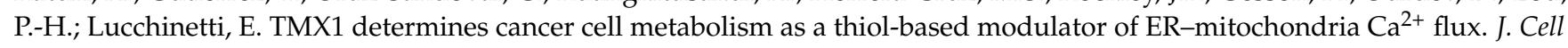
Biol. 2016, 214, 433-444. [CrossRef] [PubMed] 
119. Krols, M.; Bultynck, G.; Janssens, S. ER-Mitochondria contact sites: A new regulator of cellular calcium flux comes into play. J. Cell Biol. 2016, 214, 367. [CrossRef] [PubMed]

120. Yoboue, E.D.; Rimessi, A.; Anelli, T.; Pinton, P.; Sitia, R. Regulation of calcium fluxes by GPX8, a type-II transmembrane peroxidase enriched at the mitochondria-associated endoplasmic reticulum membrane. Antioxid. Redox Signal. 2017, 27, 583-595. [CrossRef]

121. Tubbs, E.; Rieusset, J. Metabolic signaling functions of ER-mitochondria contact sites: Role in metabolic diseases. J. Mol. Endocrinol. 2017, 58, R87-R106. [CrossRef]

122. Zhao, R.Z.; Jiang, S.; Zhang, L.; Yu, Z.B. Mitochondrial electron transport chain, ROS generation and uncoupling (Review). Int. J. Mol. Med. 2019, 44, 3-15. [CrossRef] [PubMed]

123. Mammucari, C. In the right place at the right time: ROS and $\mathrm{Ca}^{2+}$ are allies in the battle for survival. Cell Calcium 2021, 95, 102354. [CrossRef]

124. Booth, D.M.; Enyedi, B.; Geiszt, M.; Várnai, P.; Hajnóczky, G. Redox nanodomains are induced by and control calcium signaling at the ER-mitochondrial interface. Mol. Cell 2016, 63, 240-248. [CrossRef] [PubMed]

125. Nunes, P.; Demaurex, N. Redox regulation of store-operated Ca ${ }^{2+}$ entry. Antioxid. Redox Signal. 2014, 21, 915-932. [CrossRef] [PubMed]

126. Andreadou, I.; Schulz, R.; Papapetropoulos, A.; Turan, B.; Ytrehus, K.; Ferdinandy, P.; Daiber, A.; Di Lisa, F. The role of mitochondrial reactive oxygen species, $\mathrm{NO}$ and $\mathrm{H} 2 \mathrm{~S}$ in ischaemia/reperfusion injury and cardioprotection. J. Cell. Mol. Med. 2020, 24, 6510-6522. [CrossRef]

127. Beretta, M.; Santos, C.X.; Molenaar, C.; Hafstad, A.D.; Miller, C.C.; Revazian, A.; Betteridge, K.; Schröder, K.; Streckfuß-Bömeke, K.; Doroshow, J.H. Nox4 regulates InsP3 receptor-dependent $\mathrm{Ca}^{2+}$ release into mitochondria to promote cell survival. EMBO J. 2020, 39, e103530. [CrossRef]

128. Lu, L.-Q.; Tian, J.; Luo, X.-J.; Peng, J. Targeting the pathways of regulated necrosis: A potential strategy for alleviation of cardio-cerebrovascular injury. Cell. Mol. Life Sci. 2020,1-16. [CrossRef]

129. Wei, X.; Wei, X.; Lu, Z.; Li, L.; Hu, Y.; Sun, F.; Jiang, Y.; Ma, H.; Zheng, H.; Yang, G. Activation of TRPV1 channel antagonizes diabetic nephropathy through inhibiting endoplasmic reticulum-mitochondria contact in podocytes. Metabolism 2020, 105, 154182. [CrossRef]

130. Gilady, S.Y.; Bui, M.; Lynes, E.M.; Benson, M.D.; Watts, R.; Vance, J.E.; Simmen, T. Ero1 $\alpha$ requires oxidizing and normoxic conditions to localize to the mitochondria-associated membrane (MAM). Cell Stress Chaperones 2010, 15, 619-629. [CrossRef]

131. Bánsághi, S.; Golenár, T.; Madesh, M.; Csordás, G.; RamachandraRao, S.; Sharma, K.; Yule, D.I.; Joseph, S.K.; Hajnóczky, G. Isoform-and species-specific control of inositol 1, 4, 5-trisphosphate (IP3) receptors by reactive oxygen species. J. Biol. Chem. 2014, 289, 8170-8181. [CrossRef] [PubMed]

132. Marchi, S.; Corricelli, M.; Branchini, A.; Vitto, V.A.M.; Missiroli, S.; Morciano, G.; Perrone, M.; Ferrarese, M.; Giorgi, C.; Pinotti, M. Akt-mediated phosphorylation of MICU 1 regulates mitochondrial $\mathrm{Ca}^{2+}$ levels and tumor growth. EMBO J. 2019, 38 , e99435. [CrossRef]

133. Anelli, T.; Bergamelli, L.; Margittai, E.; Rimessi, A.; Fagioli, C.; Malgaroli, A.; Pinton, P.; Ripamonti, M.; Rizzuto, R.; Sitia, R. Ero1 $\alpha$ regulates $\mathrm{Ca}^{2+}$ fluxes at the endoplasmic reticulum-mitochondria interface (MAM). Antioxid. Redox Signal. 2012, 16, $1077-1087$. [CrossRef] [PubMed]

134. Li, G.; Mongillo, M.; Chin, K.-T.; Harding, H.; Ron, D.; Marks, A.R.; Tabas, I. Role of ERO1- $\alpha-$ mediated stimulation of inositol 1, 4, 5-triphosphate receptor activity in endoplasmic reticulum stress-induced apoptosis. J. Cell Biol. 2009, 186, 783-792. [CrossRef]

135. Wang, L.; Li, S.J.; Sidhu, A.; Zhu, L.; Liang, Y.; Freedman, R.B.; Wang, C.C. Reconstitution of human Ero1-Lalpha/proteindisulfide isomerase oxidative folding pathway in vitro. Position-dependent differences in role between the a and $\mathrm{a}^{\prime}$ domains of protein-disulfide isomerase. J. Biol. Chem. 2009, 284, 199-206. [CrossRef] [PubMed]

136. Park, S.J.; Lee, S.B.; Suh, Y.; Kim, S.-J.; Lee, N.; Hong, J.-H.; Park, C.; Woo, Y.; Ishizuka, K.; Kim, J.-H. DISC1 modulates neuronal stress responses by gate-keeping ER-mitochondria $\mathrm{Ca}^{2+}$ transfer through the MAM. Cell Rep. 2017, 21, 2748-2759. [CrossRef]

137. Hou, T.; Zhang, X.; Xu, J.; Jian, C.; Huang, Z.; Ye, T.; Hu, K.; Zheng, M.; Gao, F.; Wang, X.; et al. Synergistic triggering of superoxide flashes by mitochondrial $\mathrm{Ca}^{2+}$ uniport and basal reactive oxygen species elevation. J. Biol. Chem. 2013, 288, 4602-4612. [CrossRef] [PubMed]

138. Theurey, P.; Rieusset, J. Mitochondria-associated membranes response to nutrient availability and role in metabolic diseases. Trends Endocrinol. Metab. 2017, 28, 32-45. [CrossRef]

139. Zhou, Z.; Torres, M.; Sha, H.; Halbrook, C.J.; Van den Bergh, F.; Reinert, R.B.; Yamada, T.; Wang, S.; Luo, Y.; Hunter, A.H. Endoplasmic reticulum-associated degradation regulates mitochondrial dynamics in brown adipocytes. Science 2020, 368, 54-60. [CrossRef]

140. Chen, Y.-F.; Kao, C.-H.; Chen, Y.-T.; Wang, C.-H.; Wu, C.-Y.; Tsai, C.-Y.; Liu, F.-C.; Yang, C.-W.; Wei, Y.-H.; Hsu, M.-T. Cisd2 deficiency drives premature aging and causes mitochondria-mediated defects in mice. Genes Dev. 2009, 23, 1183-1194. [CrossRef]

141. Shinjo, S.; Jiang, S.; Nameta, M.; Suzuki, T.; Kanai, M.; Nomura, Y.; Goda, N. Disruption of the mitochondria-associated ER membrane (MAM) plays a central role in palmitic acid-induced insulin resistance. Exp. Cell Res. 2017, 359, 86-93. [CrossRef] [PubMed]

142. Ikeda, K.; Kang, Q.; Yoneshiro, T.; Camporez, J.P.; Maki, H.; Homma, M.; Shinoda, K.; Chen, Y.; Lu, X.; Maretich, P. UCP1independent signaling involving SERCA2b-mediated calcium cycling regulates beige fat thermogenesis and systemic glucose homeostasis. Nat. Med. 2017, 23, 1454. [CrossRef] [PubMed] 
143. Theurey, P.; Tubbs, E.; Vial, G.; Jacquemetton, J.; Bendridi, N.; Chauvin, M.A.; Alam, M.R.; Le Romancer, M.; Vidal, H.; Rieusset, J. Mitochondria-associated endoplasmic reticulum membranes allow adaptation of mitochondrial metabolism to glucose availability in the liver. J. Mol. Cell Biol. 2016, 8, 129-143. [CrossRef] [PubMed]

144. Sood, A.; Jeyaraju, D.V.; Prudent, J.; Caron, A.; Lemieux, P.; McBride, H.M.; Laplante, M.; Tóth, K.; Pellegrini, L. A Mitofusin-2dependent inactivating cleavage of Opa1 links changes in mitochondria cristae and ER contacts in the postprandial liver. Proc. Natl. Acad. Sci. USA 2014, 111, 16017-16022. [CrossRef]

145. Hailey, D.W.; Rambold, A.S.; Satpute-Krishnan, P.; Mitra, K.; Sougrat, R.; Kim, P.K.; Lippincott-Schwartz, J. Mitochondria supply membranes for autophagosome biogenesis during starvation. Cell 2010, 141, 656-667. [CrossRef] [PubMed]

146. Giorgi, C.; Ito, K.; Lin, H.-K.; Santangelo, C.; Wieckowski, M.R.; Lebiedzinska, M.; Bononi, A.; Bonora, M.; Duszynski, J.; Bernardi, R. PML regulates apoptosis at endoplasmic reticulum by modulating calcium release. Science 2010, 330, 1247-1251. [CrossRef] [PubMed]

147. Tubbs, E.; Chanon, S.; Robert, M.; Bendridi, N.; Bidaux, G.; Chauvin, M.-A.; Ji-Cao, J.; Durand, C.; Gauvrit-Ramette, D.; Vidal, H. Disruption of mitochondria-associated endoplasmic reticulum membrane (MAM) integrity contributes to muscle insulin resistance in mice and humans. Diabetes 2018, 67, 636-650. [CrossRef]

148. Rieusset, J. The role of endoplasmic reticulum-mitochondria contact sites in the control of glucose homeostasis: An update. Cell Death Dis. 2018, 9, 388. [CrossRef]

149. Samuel, V.T.; Shulman, G.I. The pathogenesis of insulin resistance: Integrating signaling pathways and substrate flux. J. Clin. Invest. 2016, 126, 12-22. [CrossRef]

150. Dingreville, F.; Panthu, B.; Thivolet, C.; Ducreux, S.; Gouriou, Y.; Pesenti, S.; Chauvin, M.-A.; Chikh, K.; Errazuriz-Cerda, E.; Van Coppenolle, F.; et al. Differential Effect of Glucose on ER-Mitochondria $\mathrm{Ca}^{2+}$ Exchange Participates in Insulin Secretion and Glucotoxicity-Mediated Dysfunction of $\beta$-Cells. Diabetes 2019, 68, 1778-1794. [CrossRef]

151. Thivolet, C.; Vial, G.; Cassel, R.; Rieusset, J.; Madec, A.-M. Reduction of endoplasmic reticulum- mitochondria interactions in beta cells from patients with type 2 diabetes. PLoS ONE 2017, 12, e0182027. [CrossRef] [PubMed]

152. Wang, C.-H.; Chen, Y.-F.; Wu, C.-Y.; Wu, P.-C.; Huang, Y.-L.; Kao, C.-H.; Lin, C.-H.; Kao, L.-S.; Tsai, T.-F.; Wei, Y.-H. Cisd2 modulates the differentiation and functioning of adipocytes by regulating intracellular $\mathrm{Ca}^{2+}$ homeostasis. Hum. Mol. Genet. 2014, 23, 4770-4785. [CrossRef] [PubMed]

153. Townsend, L.K.; Weber, A.J.; Barbeau, P.-A.; Holloway, G.P.; Wright, D.C. Reactive oxygen species-dependent regulation of pyruvate dehydrogenase kinase-4 in white adipose tissue. Am. J. Physiol. Cell Physiol. 2020, 318, C137-C149. [CrossRef] [PubMed] 